$6,1-26,2013$

\title{
Cost and impact analysis of preventive and remedial measures for safe drinking water
}

\section{A. Tahir ${ }^{1}$ and H. Rasheed ${ }^{2}$}

${ }^{1}$ National Water Quality Laboratory, Pakistan Council of Research in Water Resources, Kheyaban-e-Johar, $\mathrm{H}-8 / 1$, Islamabad, Pakistan

${ }^{2}$ Pakistan Council of Research in Water Resources, Kheyaban-e-Johar, H-8/1, Islamabad, Pakistan

Received: 3 May 2012 - Accepted: 21 May 2012 - Published: 29 January 2013

Correspondence to: M. A. Tahir (matahir2k@hotmail.com) and

H. Rasheed (hifzarasheed@mailcity.com)

Published by Copernicus Publications on behalf of the Delft University of Technology.

\section{Measures for safe} drinking water

M. A. Tahir and

H. Rasheed

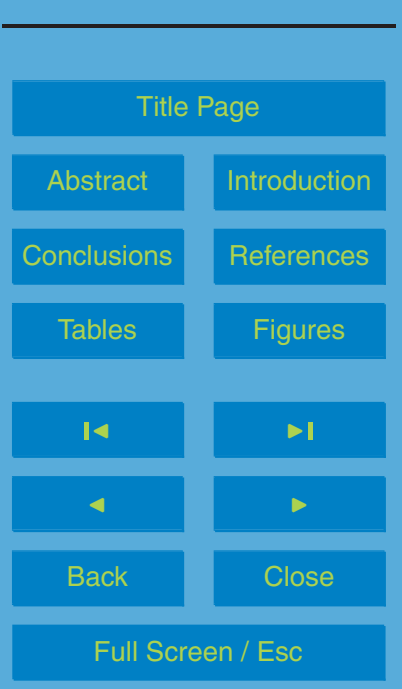

Printer-friendly Version

Interactive Discussion

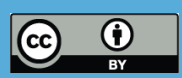




\section{Abstract}

Preventive measures yield much higher cost effective benefits as compared to remedial measures. To verify this hypothesis, a survey was conducted in two different regions of Rawalpindi district of Pakistan by comparing the cost on medication and mitigation 5 expenditures for reduction in the burden of water borne diseases. Water Quality monitoring of the study areas in comparison to WHO Drinking Water Guidelines revealed the satisfactory level of physico-chemical parameters, however; significant bacteriological contamination was found at $86 \%$ of the monitored sites in Gujar Khan and $87 \%$ in Murree region. A field questionnaire was used to estimate the expenditures on disinfection and sanitation and concluded that $8.09 \%$ of total income of each family were spent by the inhabitants of the study area on medication for water borne diseases. Correlation was worked out between the rate of water related diseases $\left(V_{\mathrm{WRD}}\right)$, unsafe drinking water $\left(C_{\mathrm{DW}}\right)$, poor sanitation $\left(P_{\mathrm{S}}\right)$, unhealthy personal hygiene and environment $\left(\mathrm{UH}_{\mathrm{PHE}}\right)$. A simulation model "Victim's Rate Calculator" was developed to forecast the estimated

15 number of victims within a population. Findings of the study verified the hypothesis that preventive measures are better choice than remedial measures due to cost benefit ratio $(1: 1.6)$ with a clear advantage of $60 \%$.

\section{Introduction}

Lack of safe drinking water and sanitation is the single largest cause of illness in the world, contributing to the death of 5 million people a year and about 5000 children every day. On the other hand, 1 billion people lack access to water and 2.6 billion people two in five people in the world do not have access to improved sanitation, defined as a simple pit latrine or better as reported by WHO and UNICEF (2005). Safe drinking water is a basic necessity and legitimate right of all human beings irrespective of their socio-economic status. Water-borne infectious disease caused by viruses, bacteria, protozoa and other microorganisms is associated with outbreaks and background rates
6, 1-26, 2013

\section{Measures for safe drinking water}

M. A. Tahir and

H. Rasheed

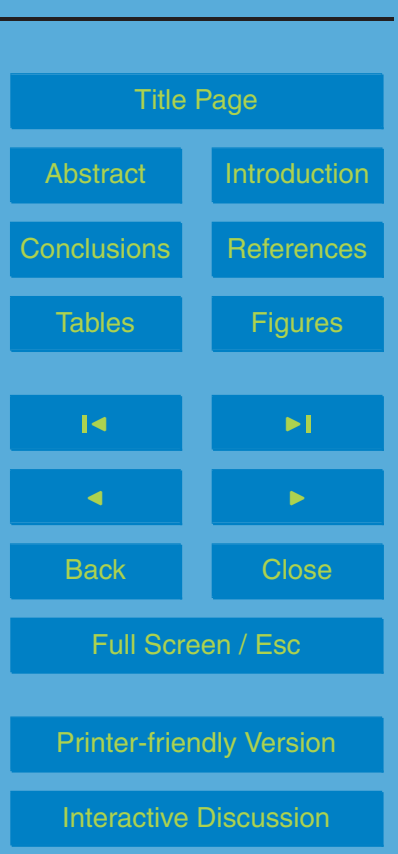


of disease in developed and developing countries worldwide. Thus, $90 \%$ of deaths from diarrhoeal diseases are children younger than five because children lack effective immune response to waterborne pathogens and toxins (WHO and UNICEF, 2005).

The most affected are the populations in developing countries, living in extreme con5 ditions of poverty, normally peri-urban dwellers or rural inhabitants. Among the main problems which are responsible for this situation are: lack of priority given to the water and sanitation sector, lack of financial resources, sustainability concerns of water supply and sanitation services, poor hygiene behaviors, and inadequate sanitation in rural areas specifically at the public places including hospitals, health centers and schools. 10 The 21st century vision about drinking water is to concentrate and adopt the concept of preventive measures rather than sticking to remedial measures as practiced in all the developing countries during the 20th century. A number of studies documented by FAO and $\mathrm{WHO}$ had confirmed the importance of preventive measures over the remedial ones (Tahir, 1989). World Health Organization (WHO) technical reports have revealed 15 that after installation of safe water pipes alone in 30 rural settlements of Japan, communicable intestinal diseases were reduced by $71.5 \%$ and that of trachoma by $64 \%$ (i.e infection of the mucous membrane of the eyelids caused by the bacterium Chlamydia trachomatis), while the death rate for infants and young children fell by $51.7 \%$. Similarly, in Uttarpardesh (India), after improvements in water works sewerage and sanitation, the cholera death rate decreased by $74.1 \%$, the typhoid fever death rate by $63.3 \%$ and the dysentery by $23.1 \%$ (Ray et al., 2000).

Preventive actions are generally taken if there is a chance of outbreaks of waterborne and water related diseases. One of the success stories of preventive actions is polio drop campaign all over the world. IPOL (Poliovirus Vaccine Inactivated) is given to infants (as young as 6 weeks of age), children, and adults to prevent polio caused by poliovirus Types 1, 2, and 3. Patient suffering from polio disease needs much finance for medicines and prolonged treatment. Therefore, preventive measures are justified as much better choice than taking remedial measures after problem occurrence. Studies like these have shown that timely prevention is not only better for health but also
$6,1-26,2013$

\section{Measures for safe drinking water}

M. A. Tahir and

H. Rasheed
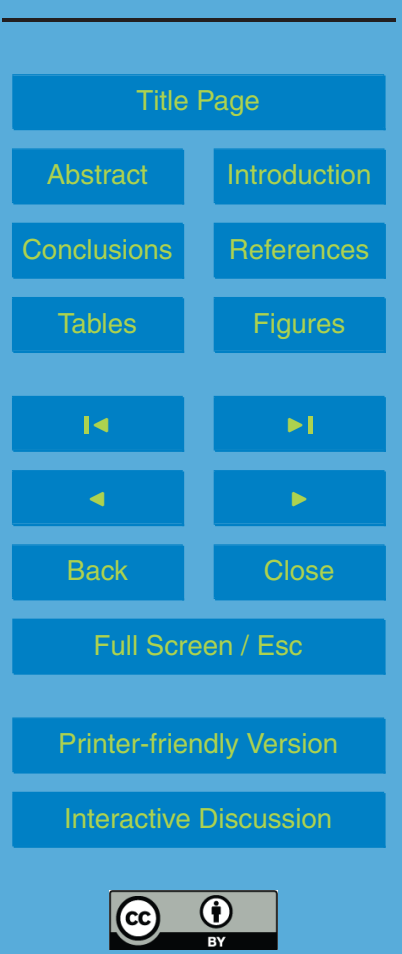
comparatively less expensive. This research concept is highly applicable in the drinking water sector with systematic integration of preventive measures.

It is more feasible and economical to improve or optimize the water supply infrastructure by adopting the cost effective water quality treatment techniques. Otherwise, it may 5 create an obligatory situation for the Governments and other health related agencies to make huge investments on medication of diversified water borne diseases, hospital infrastructure and man power etc. The sufferings of the patients due to water borne diseases will also have direct and indirect consequences for masses along with other socio-economic problems in the society. Considering such unwanted situations, the 10 objectives of the study were; to investigate the water quality problems and water related diseases in the selected study area; to co-relate the health hazards to poor water quality; to develop cost relationship between preventive and remedial measures and; to develop simulation model for the prediction of victim's rate in relation to water borne diseases. The outcome of this study negates the perception of most of the policy makers of developing countries that the sufficient funds cannot be allocated to improve water quality situations being a poor nation. However, situation in case of investments in water and sanitation sector in developed countries is more attractive due to better benefit to cost ratio as proved by this study.

\section{Experimental section}

20 The target areas for this case study consisted of Gujar Khan and Murree tehsils in Rawalpindi district. The district has five tehsils i.e., Gujar Khan, Kahuta, Murree, Rawalpindi, and Taxila having three topographical categories i.e. plain, semi hilly and hilly areas (Table 1).

Two types of field proforma were used: (i) village profile, which was used during 25 the drinking water sampling, reflects the basic information regarding the village such as: household numbers, major occupations of inhabitants, type of roads, education and health facilities, literacy rate, ratio of male and female, water supply and sanitary
$6,1-26,2013$

\section{Measures for safe drinking water}

M. A. Tahir and

H. Rasheed

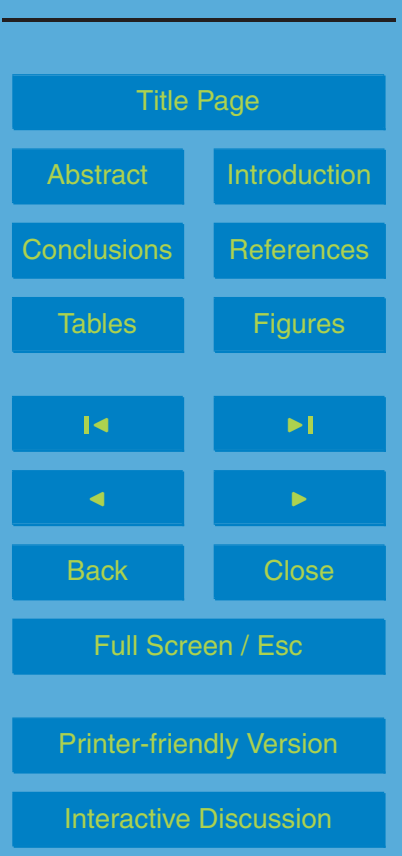


drainage system etc., In total, $10 \%$ of households were selected randomly from each village around the basic health units for using this village profile. (ii) Household profile, which was used to collect statistics on family members, family literacy rate, basic health facilities and sanitation. The type of information for compilation of these statis5 tics included but not limited to: average income per family per month, distance of Basic Health Units (BHU) from home, availability of doctor and medicines, medication cost, when ill, the preference of patients to go for treatment i.e. Basic Health Unit, hospital, dispensary, homoeopathic, medical store or any other, suggestion for the improvement of Basic Health Unit, frequency of visit to BHU in a year for treatment, possible rea10 son of illness due to diseases such as; Water Borne Diseases: (Typhoid, Cholera, Infective Hepatics, Dysentery, Enteric Diarrhocas), Water Washed Diseases: (Scabies, Trachoma, Dysentery), Water Based Diseases: (Schistomiasis, Guinea Worm), Water Related Vector Diseases: (Malaria, Yellow Fever, Onchoarciasis), Chemical Based Diseases: (Methaemoglobinaemia, Fluorosis, Toxic Metal Sickness) and Sanitation Based 15 Diseases:(Hook Worm, Ascariasis, Trichuris, Leprospiroris), charges of treatment other than BHU, number of illness suffering days, average loss of income per day due to ailment of respondent, drinking water sources, contamination sources and treatments available to respondent, types of sanitation/drainage facilities, if any available to the respondents. Based on the information collected through village and household profiles, data analysis was done to develop a relationship between comparative economic cost of health and drinking water treatment. A summary of such information is given in Table 2.

The information collected through this survey was utilized to develop correlation between water quality, expenditure to be incurred due to water-related diseases and expenditure to be needed for preventive measures. Based on this correlation, a simulation model in Microsoft Visual Basic backed by a Database built in Microsoft Access was developed to forecast the possible number of victims of water borne diseases within a given community.
6, 1-26, 2013

\section{Measures for safe drinking water}

M. A. Tahir and

H. Rasheed

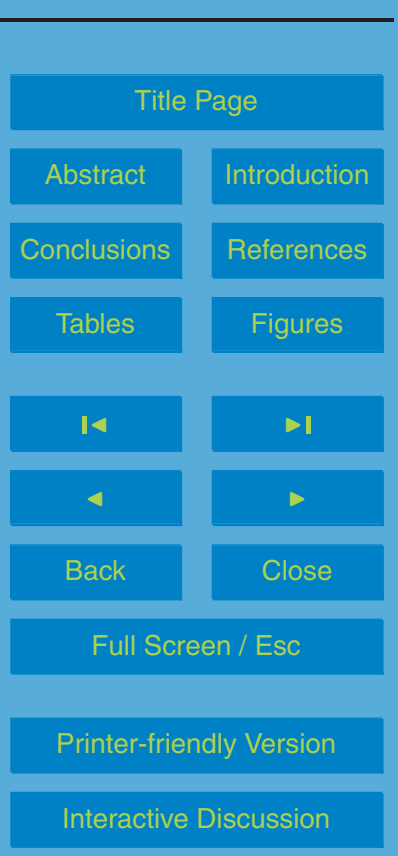




\section{Results and discussion}

In total, 300 drinking water samples were collected from the study areas and analyzed for 22 basic physico-chemical and microbiological parameters (alkalinity, aluminum, bicarbonates, carbonates, calcium, chloride, copper, electrical conductivity, 5 free $\mathrm{CO}_{2}$, hardness, iron, magnesium, manganese, nitrate $(\mathrm{N}), \mathrm{pH}$, phosphate, potassium, sodium, Total Dissolved Solids, zinc, Total Coliforms and E-coli) in National Water Quality Laboratory of PCRWR. Analytical findings were compared with World Health Organization Drinking Water Guideline values (WHO, 2006) to conclude the contamination load.

10 There was no significant problem of chemical contamination in both the tehsils except slightly excessive Nitrate (N) in Gujar Khan and iron contents in Murree tehsil (Table 3), however; the bacteriological quality of drinking water in 06 villages (i.e Rajoha, Banote, Jajja, Jungal, Gojra and Baghana) of Tehsil Gujar Khan and in 04 villages (Jugial, Dhol Koni Dana, Durrah Gali, and Phagwari) of Tehsil Murree was evaluated as unsafe due to presence of Total Coliforms and E-coli (Figs. 1 and 2).

An analysis of data collected using field questionnaire on socio-economic aspects from households and basic health units revealed that $32.84 \%$ populations were suffering from water borne and water related diseases in the area. The percentage distribution of water related cases included dysentery (23.79\%), diarrhea (5.37\%), scabies $20 \quad(21.48 \%)$, malaria $(20.46 \%)$, hookworm $(9.21 \%)$, cholera $(6.91 \%)$, and goiter $(6.65 \%)$ and other water related diseases such as typhoid $(1.79 \%)$, ascariases $(0.51 \%)$ as detailed in Table 4.

Findings were actualized in respect of economic facts due to contaminated water supply on the basis of collected information. It was concluded that $8.09 \%$ of total income of each family in Pakistan is being spent on medication of water related diseases based on correlation between expenditure incurred on medicine and total income of the family per month. The precise digest of this analysis is presented in Table 5.
$6,1-26,2013$

\section{Measures for safe drinking water}

M. A. Tahir and

H. Rasheed

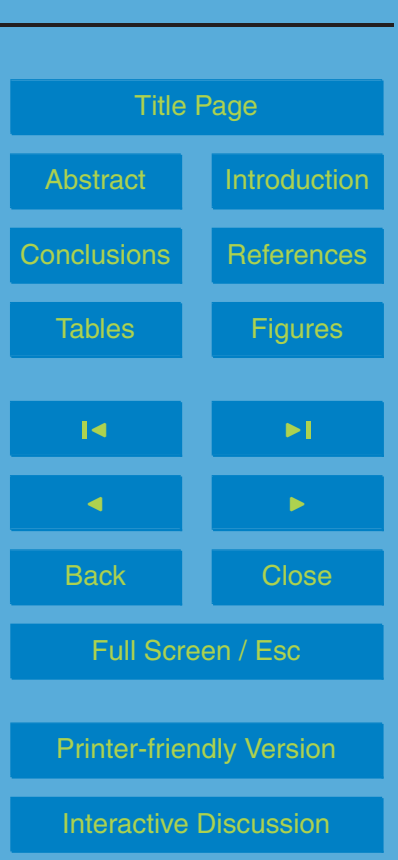


For estimating the water treatment expenditures, water demand per capita was required. Minimum water quantity per capita is the estimate to be needed for maintaining human survival. Basic human requirements of water are given in Table 6 according to recommendations of Gleick (1999).

5 A review of studies from developed and developing countries (Howard and Bartram, 2003; Chenoweth, 2007; NRC, 1999; UNESCO, 2003; WHO, 2006) have suggested that an average of 10 to 20 I per person will meet basic needs. Minimum drinking water requirements have been estimated at about three liters per day under average temperate climate conditions. With changing climate and levels of activity, these daily minimum 10 water requirements can also increase. However, domestic water requirement of many countries has been estimated below $100 \mathrm{~L}$ per person per day and is also assumed sufficient for domestic water requirement. Keeping in view of water quality data, estimates were calculated assuming $100 \mathrm{~L}$ water requirements per capita per day on the basis of low-cost, simple and dependable water treatment i.e., appropriate chlorination 15 for the provision of safe drinking water to the inhabitants of the study area. Tri-ChloroIso-Cyanuric Acid (TCICA) is water-soluble (12 gram per liter at $25^{\circ} \mathrm{C}$ ) having $90 \%$ active Chlorine and is best for effective disinfection. Summing up, the overall water requirement 43471 cubic meters per year is needed, $277 \mathrm{~kg}$ of TCICA for Chlorination of 1191 family members (155 families @ $>7$ members per family) of study area at the rate of $100 \mathrm{~L}$ per capita per day. The details of expenditure to be spent for the disinfection process are as given in Table 7.

To improve $100 \%$ sanitation conditions, 155 toilets (one per each family) were required in that area. An amount of Rs. 11574 (USD 178.00) was calculated for one low cost toilet with life span of $40 \mathrm{yr}$ and having width and length of $4 \times 4$ feet, height of 7 feet with walls of 4.5 inches brick masonry (1:6 cement mortars), roof of 3 or 4 inches thick concrete slabs cover the whole toilet with WC ceramic. As the concrete structures have an average service life of $60 \mathrm{yr}$ (Lemay and Leed, 2011), however, calculations are made on the basis of $40 \mathrm{yr}$ life span depending on several environmental
$6,1-26,2013$

\section{Measures for safe drinking water}

M. A. Tahir and

H. Rasheed

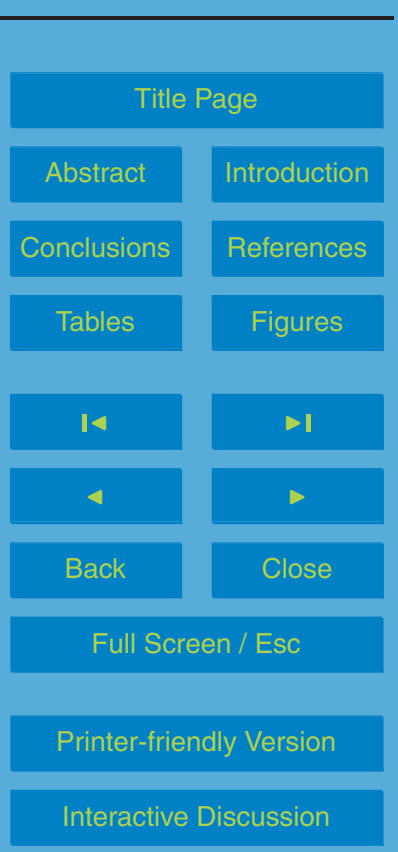


and other factors. Horizontal and vertical X-sections of toilet are shown in Figs. 3 and 4, respectively. The cost of improved sanitation for 155 families is calculated as following:

i. Expenditure on 155 units $=11574 \times 155=$ Rs. $1793970 \cong$ USD 27599.00

ii. Cost per year for sanitation system $=1793970 / 40=$ Rs. $44849 \cong$ USD 690

5 Therefore, total cost to improve water and sanitation conditions in study area was Table 8.

In view of the above actualities regarding economic statistics collected through field questionnaire, it is unquestionably established that an amount of Pak Rs 2, 99706 (USD 4611.00) was being spent on medicine per year to deal with water related diseases as remedial measures. However, some distinct and significant factors that can absolutely increase the estimation are not considered at this moment due to certain limitations. These factors include Loss of working hours, hardship for depended family members, expenditure on infrastructure for medical facilities, expenses on transportation and nutritional needs, manpower looking after the patients, reduction in life 5 expectancy rate, Immunity loss and anxiety.

Concluding the above estimates, an amount of Pak Rs. 181054 (USD 2785.00) was needed to improve water and sanitation facilities against the expenditure of Rs. 299706 (USD 4611.00) in the study area, assuming no cost needed for the improvement of personnel hygiene and environment. The improvement in personnel hygiene and environment can easily be achieved through education by means of print and electronic media. Mosques in the target areas can also play an effective role in this regard. It may be concluded from the ratio $(1: 1.66)$ of both costs that the preventive measures are better choice for water supply improvement like polio handling in the developing countries.

25 The benefit-cost analysis is often used to determine the acceptability of various projects in the public sector. Conceptually, it is an analysis considering the worthiness of allocating resources to a project and the extent to which the benefits exceed the costs for the various alternatives. The mechanisms of the benefit-to-cost
$6,1-26,2013$

\section{Measures for safe drinking water}

M. A. Tahir and

H. Rasheed

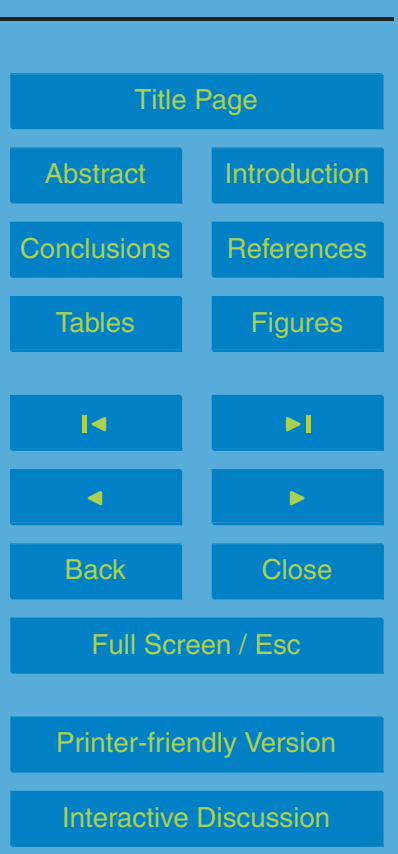

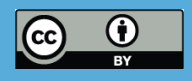


comparisons are straightforward and simple for calculating the highest Benefit-to-Cost ratio $(B / C)$. In this case, comparison between the Benefit $(B=$ saving of the expenditures occurred to purchase medicines i.e., Rs. 2, $99706 \cong$ USD 4611.00) and the Cost $(\mathrm{C}=$ Expenditure to be needed to improve water and sanitation facilities i.e., Rs. $5181054 \cong$ USD 2785.00) is very reasonable. Therefore, the determined Benefit-to-Cost ratio $(B / C)=299706 / 181054=1.66(B / C>1)$. B/C greater than 1 , indicates a good alternative, which can be adopted as a better option in future projects by the policy and decision makers.

\subsection{Victim's Vs drinking water, sanitation and PHE}

10 Hypothetically and truly three main factors are considered to reduce water related diseases that are ultimately responsible for excessive motility (M) and morbidity (MO) rates. These include main factors Drinking Water, Sanitation, Personal Hygiene and Environment. The rate of water related diseases are directly proportional to unsafe water quality or contaminated drinking water $\left(C_{\mathrm{DW}}\right)$, poor sanitation $\left(P_{\mathrm{S}}\right)$ and unhealthy 15 personal hygiene and environment $\left(\mathrm{UH}_{\mathrm{PHE}}\right)$. We may make this statement in an alternative way that the contaminated water quality, poor sanitation and lack of personal hygiene and unhealthy environment can increase the victims' rate $\left(V_{\mathrm{WRD}}\right)$. Mathematically, it can be written as:

$V_{\mathrm{WRD}}$ rate $\alpha\left(C_{\mathrm{DW}}+P_{\mathrm{S}}+\mathrm{UH}_{\mathrm{PHE}}\right) / 3$ or

$20 \quad\left[V_{\mathrm{WRD}}\right.$ rate $\left.=k\left(C_{\mathrm{DW}}+P_{\mathrm{S}}+\mathrm{UH}_{\mathrm{PHE}}\right) / 3\right]$

Where $k$ is a constant.

Victims' rate due to water related diseases (in three categories) in the study area and ratio for each category are calculated with the help of data shown in Table 9.

Share and ratio in three categories is self explanatory and presented as under:

\section{$6,1-26,2013$}

\section{Measures for safe drinking water}

M. A. Tahir and

H. Rasheed

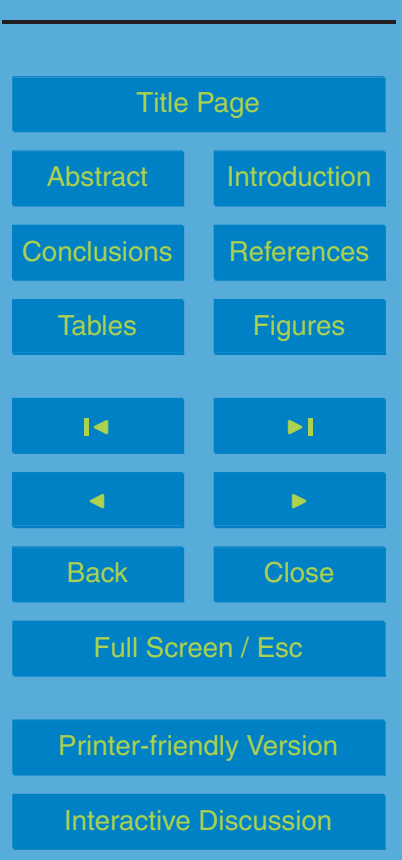

b. Share of diseases over total population in $P_{S}$ Category $=10.08 \%$ 
C. Share of diseases over total population in $\mathrm{UH}_{\mathrm{PHE}}$ Category $=6.72 \%$

d. $C_{\mathrm{DW}} \%$ in study area $=87 \%$ (based on water quality assessment)

e. $P_{\mathrm{S}} \%$ in study area $=82 \%$ (based on sanitation facilities from household profile)

f. $\mathrm{UH}_{\mathrm{PHE}} \%$ in study area $=51 \%$ (based on illiteracy rate from household profile)

5 g. $V_{\text {WRD }}$ rate in the study area $=32.84 \%$ (391 from 1191 population)

h. $V_{\text {WRD }}$ rate if $C_{\text {DW }}(100 \%)=16.04 / 87 \times 100=18.44$

i. $V_{\mathrm{WRD}}$ rate if $P_{\mathrm{S}}(100 \%)=10.07 / 82 \times 100=12.28$

j. $V_{\mathrm{WRD}}$ rate if $\mathrm{UH}_{\mathrm{PHE}}(100 \%)=6.72 / 51 \times 100=13.18$

k. $V_{\mathrm{WRD}}$ rate $=43.9 \%$ (Based on study)

I. Ratio $\left(\mathrm{UH}_{\mathrm{PHE}}: P_{\mathrm{S}}: C_{\mathrm{DW}}\right)=1.073: 1: 1.5$

By putting these values in Eq. (1), we can find

$\left[V_{\mathrm{WRD}}\right.$ rate $\left.=k\left\{\left(1.5 C_{\mathrm{DW}}+P_{\mathrm{S}}+1.073 \mathrm{UH}_{\mathrm{PHE}}\right) / 3\right\}\right]$

Where $k$ is a constant and is equal to 0.3687 , which is derived from Eq. (2) by putting actual values from data as shown below:

$32.84=K[(1.5 \times 87+82 \times 1.073 \times 51) / 3]$

$\left[V_{\mathrm{WRD}}\right.$ rate $=0.3687\left\{\left(1.5 C_{\mathrm{DW}}+P_{\mathrm{S}}+1.073 \mathrm{UH}_{\mathrm{PHE}}\right) / 3\right]$

With the help of the Eq. (3), victim's rate can be predicted respecting water-related diseases by putting values for $C_{\mathrm{DW}}(\%), P_{\mathrm{S}}(\%), \mathrm{UH}_{\mathrm{PHE}}(\%)$.
$6,1-26,2013$

\section{Measures for safe drinking water}

\section{A. Tahir and}

H. Rasheed

\section{Title Page}

\section{Abstract}

Introduction

Conclusions

Tables

References

Figures

14

$>1$

4

Back

Close

Full Screen / Esc

Printer-friendly Version

Interactive Discussion 


\subsection{Simulation model for victim's rate}

Victim's rate calculator was developed using Microsoft Visual Basic as a front-end program with Microsoft Access as a database. There are following three basic inputs in this program.

i. $C_{\mathrm{DW}}$ (Contaminated Drinking Water) in Percent.

ii. $P_{\mathrm{S}}$ (Poor Sanitation) in Percent.

iii. $U_{\mathrm{PHE}}$ (Unhealthy Personal Hygiene and Environment) in Percent.

The final value for $V_{\text {WRD }}$ can be calculated by putting values of these three inputs. The $V_{\text {WRD }}$ Calculator verified against various statistics proved a useful programme for 10 estimating the number of Victims within a given population. The $V_{\text {WRD }}$ is based on following formula:

$V_{\mathrm{WRD}}$ Rate $=K\left[\left(1.5 C_{\mathrm{DW}}+P_{\mathrm{S}}+1.073 \mathrm{UH}_{\mathrm{PHE}}\right) / 3\right]$

$$
\{K=0.3687\}
$$

\section{Conclusions}

15 Despite the facts, that most of the diseases are waterborne and are responsible for higher number of morbidity and mortalities. Now it is a universally recognized that safe drinking water supplies, improved sanitation and better personal hygiene can improve the quality of life, human efficiency, effectiveness, mortality, morbidity and life expectancy rates. It is a bitter fact in developing and least developed countries that neither the public nor the policy and decision maker are well aware of the gravity of the situation which may be prevailing due to less awareness, low literacy rate, political instability, socio-cultural problem, low priority to enhance their safe water supply coverage and lack of any model for economic feasibility between preventive and remedial
6, 1-26, 2013

\section{Measures for safe drinking water}

M. A. Tahir and

H. Rasheed

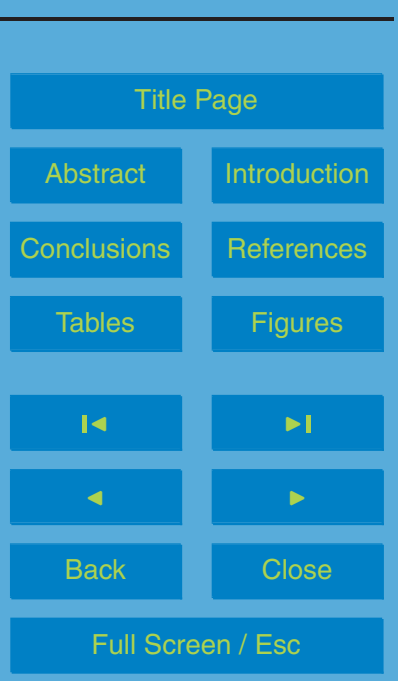

Printer-friendly Version

Interactive Discussion

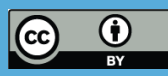


measures. Correlation between preventive and remedial measures proved the concept of taking preventive measures as the principal priority and is far better than treatment. $\mathrm{B} / \mathrm{C}$ ratio $(1.66, \mathrm{~B} / \mathrm{C}>1)$ also indicated a righteous alternative and is strongly recommended to implement this option in water and sanitation sector on the format of polio 5 preventive treatment approach, which was adopted countrywide. This will uplift the standard of life of common and poor population. The computer simulation model for the prediction of victim's rate will also be helpful to create awareness and initiation of timely preventive actions. Gateways are open for further research studies in the similar sphere.

\section{References}

APHA, AWWA and WEF: Standard Methods for the Examination of Water and Wastewater, American Public Health Association, American Water Works Association and Water Environment Federation, 21st Edn., Washington DC, 2-1 to 9-55, 2005.

Chenoweth, J.: Minimum Water Requirement for Social and Economic Development, Desalination, 229, 245-256, 2007.

Gleick, P. H.: Basic Water Requirements for Human Activities: Meeting Basic Needs, in: The Human Right to Water, Pacific Institute for Studies in Development, Environment and Security, USA, 84-88, 1999.

Howard, G. and Bartram, J.: Domestic Water Quantity, Service Level and Health, World Health Organization Document Production Services, Geneva, Switzerland, WHO/SDE/WSH/03.02, 4-6, 2003.

Lemay, L. and Leed, A. P.: Life Cycle Assessment of Concrete Buildings. Sustainable Development, NRMCA, Concrete Sustainability Report, National Ready Mixed Concrete Association CSR04-October, 2011.

25 NRC: Recommended Dietary Allowances, 10th Edn., Subcommittee on the Tenth Edition of the RDAs, Food and Nutrition Board Commission on Life Sciences, National Research Council; National Academy Press, Washington, DC, USA, 247-250, 1999.
6, 1-26, 2013

\section{Measures for safe drinking water}

M. A. Tahir and

H. Rasheed

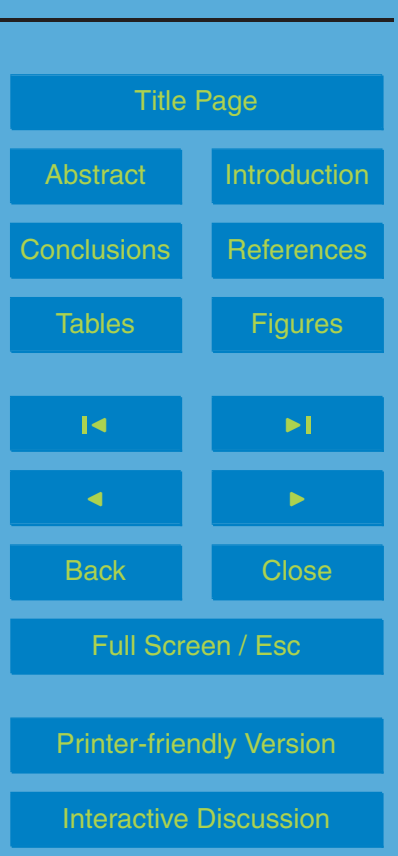

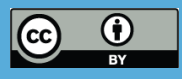


Ray, B. D., Mazhari, H. K., Passah, P. M., and Pandey, M. C.: Population, Poverty and Environment in North East India, Noth East India Council for Social Science Research, Shillong, Concept Publishing Company, New Delhi, India, 318 pp., 2000.

Tahir, M. A.: Pollution Problems in the Water Supply Systems of Islamabad and Rawalpindi, 5 Technical Report of the Pakistan Council of Research in Water Resources, Islamabad, Pakistan, 10-15, 1989.

UNESCO: World Water Assessment Programme, Water for People, Water for Life: The United Nations World Water Development Report, UNESCO Publishing, Berghahn Books, Paris, 7-23, 2003.

WHO: Guidelines for Drinking-Water Quality: incorporating first addendum, 3rd Edn., World Health Organization, Geneva, 210-459, 2006.

WHO and UNICEF: Joint Monitoring Programme for Water Supply and Sanitation, World Health Organization and United Nation's Children Education Funds, Water for Life: Making It Happen, 4-10, 2005, http://www.who.int/water_sanitation_health/waterforlife.pdf, last access: 21

\section{$6,1-26,2013$}

\section{Measures for safe drinking water}
M. A. Tahir and
H. Rasheed

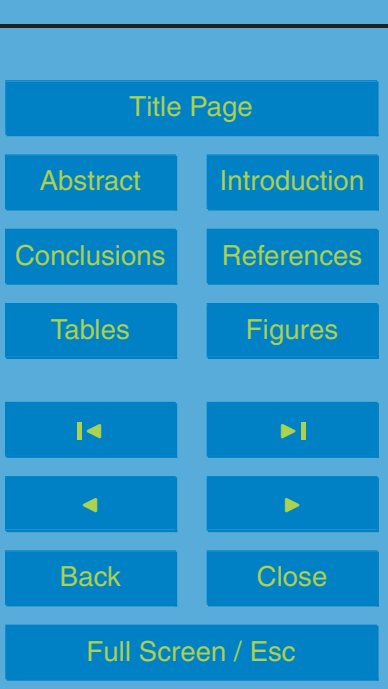

Printer-friendly Version

Interactive Discussion 
Table 1. Water sources and topography.

\begin{tabular}{llll}
\hline Sr. \# & Tehsil & Water Sources & Topography \\
\hline 1 & Gujar Khan & $\begin{array}{l}\text { Well, Tube well, Hand pump, } \\
\text { Water supply and pond }\end{array}$ & Plain and semi-hilly area \\
\hline 2 & Murree & Spring, well, water supply & Hilly area \\
\hline 3 & Kahuta & $\begin{array}{l}\text { Well, Hand pump, water supply, } \\
\text { spring }\end{array}$ & Hilly area \\
\hline 4 & Taxila & Well, Tube well, spring & Plain and semi-hilly area \\
\hline 5 & Rawalpindi & $\begin{array}{l}\text { Well, Tube well, Hand pump, } \\
\text { water supply }\end{array}$ & Plain and semi-hilly area \\
\hline
\end{tabular}

\section{Measures for safe drinking water \\ M. A. Tahir and \\ H. Rasheed}
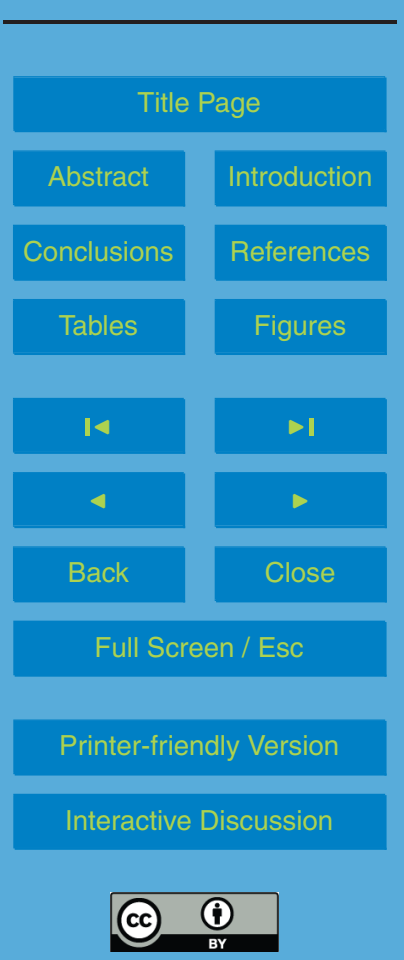
Table 2. Important facts about study area.

\begin{tabular}{|c|c|c|}
\hline 1. & Total families interviewed & 155 No. \\
\hline 2. & Total family members & 1191 Nos. \\
\hline 3. & Literate & 611 No. \\
\hline 4. & Literacy rate & $51.30 \%$ \\
\hline 5. & Average income per family per month & Rs. 1992 \\
\hline 6. & $\begin{array}{l}\text { Basic Health Unit: } \\
\text { i. Approachable } \\
\text { ii. Non approachable }\end{array}$ & $\begin{array}{l}70.32 \% \\
29.68 \%\end{array}$ \\
\hline 7. & Patients satisfied from $\mathrm{BHU}$ & $15.48 \%$ \\
\hline 8. & Patients not satisfied from $\mathrm{BHU}$ & $84.52 \%$ \\
\hline 9. & $\begin{array}{l}\text { Drinking water sources; } \\
\text { i. Well } \\
\text { ii. Spring } \\
\text { ii. Hand Pump } \\
\text { iii. Tap }\end{array}$ & $\begin{array}{l}41.29 \% \\
35.48 \% \\
20.65 \% \\
4 \%\end{array}$ \\
\hline 10. & Families treating water with chemicals & $12.26 \%$ \\
\hline 11. & Families with proper sanitation and drainage & None \\
\hline 12. & Families using open field latrine & $81.94 \%$ \\
\hline 13. & Families using pit latrine & $18.06 \%$ \\
\hline 14. & Total numbers of water related cases & 391 \\
\hline 15. & Population suffering with water related diseases per year & $32.84 \%$ \\
\hline 14. & Annual medical expenditures on all families & $\begin{array}{l}\text { Rs. } 299706 \\
\text { (USD* 4611.00) }\end{array}$ \\
\hline 15. & Annual medical expenditures per family & $\begin{array}{l}\text { Rs. } 1934 \\
\text { (USD* } 30.00)\end{array}$ \\
\hline
\end{tabular}

* 1 USD equivalent to Rs. 64.4 at the time of study.

6, 1-26, 2013

\section{Measures for safe drinking water}
M. A. Tahir and
H. Rasheed

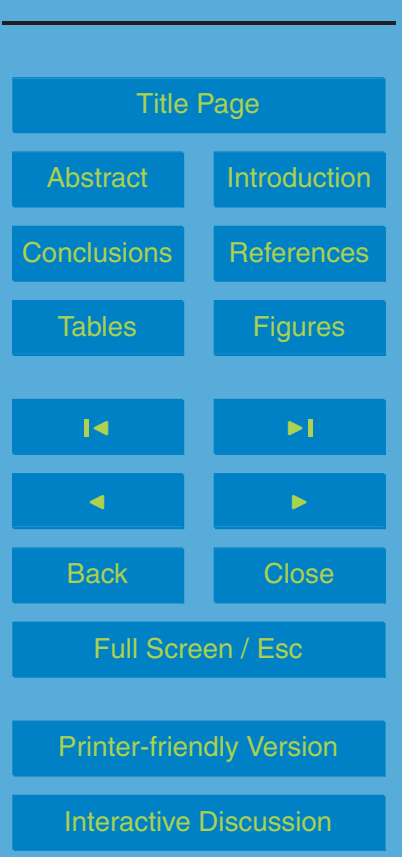


Table 3. Physico-chemical water quality of Gujar Khan and Murree Tehsils.

\begin{tabular}{|c|c|c|c|c|c|c|c|c|c|}
\hline \multirow{2}{*}{$\begin{array}{l}\text { Sr. } \\
\#\end{array}$} & \multirow[t]{2}{*}{ Parameters } & \multirow[t]{2}{*}{ Unit } & \multirow{2}{*}{$\begin{array}{l}\text { Guideline } \\
\text { Values }\end{array}$} & \multicolumn{3}{|c|}{ Gujar Khan } & \multicolumn{3}{|c|}{ Murree } \\
\hline & & & & Mean & Max & Min & Mean & Max & Min \\
\hline 1 & Alkalinity & $\mathrm{m} \mathrm{moll}^{-1}$ & NGVS & 7.67 & 15.6 & 2 & 5.55 & 8.2 & 3 \\
\hline 2 & Aluminum & $\mathrm{mgl}^{-1}$ & $0.2(\mathrm{WHO})$ & 0.08 & 0.3 & 0 & - & - & - \\
\hline 3 & Bicarbonates & $\mathrm{mgl}^{-1}$ & NGVS & 383 & 780 & 100 & 278 & 410 & 150 \\
\hline 4 & Carbonates & $\mathrm{mgl}^{-1}$ & NGVS & 0.69 & 10 & 0 & 0 & 0 & 0 \\
\hline 5 & Calcium & $\mathrm{mgl}^{-1}$ & 75 (KSA) & 32 & 76 & 3 & 35 & 66 & 20 \\
\hline 6 & Chloride & $\mathrm{mgl}^{-1}$ & 250 (WHO) & 129 & 1540 & 17.7 & 26 & 96 & 14 \\
\hline 7 & Copper & $\mathrm{mgl}^{-1}$ & $1(\mathrm{WHO})$ & 0.073 & 0.17 & 0 & 0.02 & 0.11 & 0 \\
\hline 8 & EC & $\mu S \mathrm{~cm}^{-1}$ & NGVS & 983 & 5500 & 103 & 318 & 532 & 173 \\
\hline 9 & Free $\mathrm{CO}_{2}$ & $\mathrm{mgl}^{-1}$ & NGVS & 0.67 & 1.1 & 0 & 0.99 & 1.9 & 0.27 \\
\hline 10 & Hardness & $\mathrm{mgl}^{-1}$ & $500(\mathrm{WHO})$ & 353 & 825 & 125 & 336 & 537 & 74 \\
\hline 11 & Iron & $\mathrm{mgl}^{-1}$ & $0.3(\mathrm{WHO})$ & 0.06 & 0.14 & 0 & 0.24 & 0.39 & 0.05 \\
\hline 12 & Magnesium & $\mathrm{mgl}^{-1}$ & 150 (Canadian) & 26 & 89 & 3 & 47 & 29 & 5 \\
\hline 13 & Manganese & $\mathrm{mgl}^{-1}$ & $0.1(\mathrm{WHO})$ & 0.19 & 0.81 & 0 & 0.04 & 0.2 & 0 \\
\hline 14 & Nitrate $(\mathrm{N})$ & $\mathrm{mgl}^{-1}$ & $10(\mathrm{WHO})$ & 11 & 72 & 0.3 & - & - & - \\
\hline 15 & $\mathrm{pH}$ & - & $6.5-8.5$ & 7.53 & 8.33 & 7.02 & 7.26 & 7.97 & 6.35 \\
\hline 16 & Phosphate & $\mathrm{mgl}^{-1}$ & $1-5$ & 0.02 & 0.06 & 0 & 0.01 & 0.04 & 0 \\
\hline 17 & Potassium & $\mathrm{mgl}^{-1}$ & NGVS & 2.54 & 7.8 & 0.5 & 1.76 & 9.1 & 0.3 \\
\hline 18 & Sodium & $\mathrm{mgl}^{-1}$ & 200 (WHO) & 185 & 1520 & 4 & 11 & 27 & 3 \\
\hline 19 & T.D.S. & $\mathrm{mgl}^{-1}$ & 1000 & 585 & 3280 & 61 & 189 & 317 & 102 \\
\hline 20 & Zinc & $\mathrm{mgl}^{-1}$ & $5(\mathrm{WHO})$ & 0.16 & 0.76 & 0 & 0.09 & 0.7 & 0.01 \\
\hline
\end{tabular}

$6,1-26,2013$

\section{Measures for safe drinking water}
M. A. Tahir and
H. Rasheed

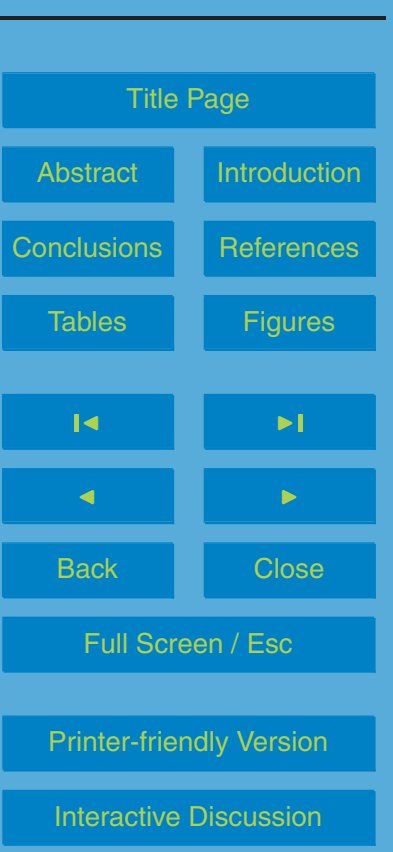


Table 4. Water related diseases and their pertinent information.

\begin{tabular}{lllll}
\hline $\begin{array}{l}\text { Sr. } \\
\#\end{array}$ & $\begin{array}{l}\text { Water Related } \\
\text { Diseases }\end{array}$ & $\begin{array}{l}\text { Total Patients } \\
(\text { No.) }\end{array}$ & $\begin{array}{l}\text { Overall Share } \\
(\%) \text { of Each } \\
\text { Disease }\end{array}$ & $\begin{array}{l}\text { Overall Share (\%) of } \\
\text { Each Disease from } \\
\text { Total Population }\end{array}$ \\
\hline 1. & Dysentery & 93 & 23.79 & 7.81 \\
2. & Enteric Diarrheas & 21 & 5.37 & 1.76 \\
3. & Scabies & 84 & 21.48 & 7.05 \\
4. & Hook Worm & 36 & 9.21 & 3.03 \\
5. & Malaria & 80 & 20.46 & 6.72 \\
6. & Goiter & 26 & 6.65 & 2.18 \\
7. & Cholera & 27 & 6.91 & 2.27 \\
8. & Typhoid & 7 & 1.79 & 0.59 \\
9. & Ascaris & 2 & 0.51 & 0.17 \\
10. & Others & 15 & 3.84 & 1.26 \\
\hline 11. & Total & & \multicolumn{2}{c}{391} \\
\hline
\end{tabular}

$6,1-26,2013$

\section{Measures for safe drinking water
M. A. Tahir and
H. Rasheed

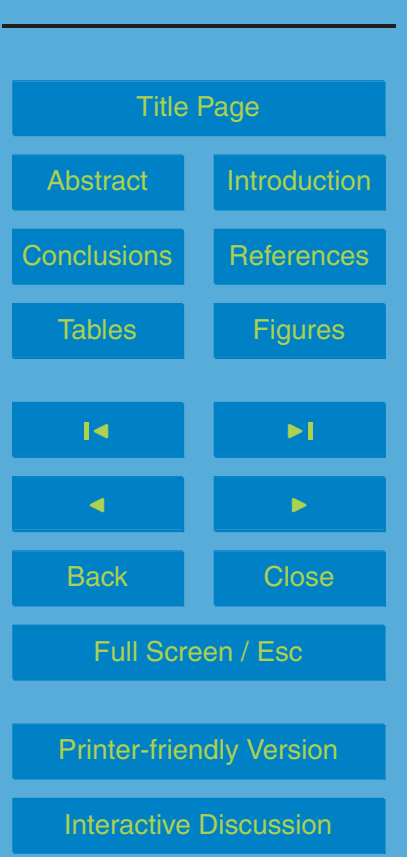


Table 5. Economic facts due to unsafe water supplies (in Rupees).

\begin{tabular}{llll}
\hline Sr. No & Socio-Economic Facts & \multicolumn{2}{c}{ Share } \\
\cline { 3 - 4 } & & Pak Rupees & USD $^{*}$ \\
\hline 1. & Annual Income of all families & 3705600 & 57009.00 \\
\hline 2. & Monthly Income of all families & 308800 & 4751.00 \\
\hline 3. & Annual Income of Single family & 23907 & 3678.00 \\
\hline 4. & Average family income per month & 1992 & 31.00 \\
\hline 5. & Average income per person per year & 3111 & 48.00 \\
\hline 6. & Average income per person per month & 259 & 4.00 \\
\hline 7. & $\begin{array}{l}\text { Average expenditure on medicines } \\
\text { (Water Related Diseases) per family per year }\end{array}$ & 1934 \\
\hline 8. & $\begin{array}{l}\text { Average expenditure on medicines per family } \\
\text { per month }\end{array}$ & 161 & 2.5 \\
\hline 9. & $\begin{array}{l}\text { Average expenditure on medicines per person } \\
\text { per year }\end{array}$ & 252 & 3.9 \\
\hline 10. & $\begin{array}{l}\text { Average expenditure on medicines per person } \\
\text { per month }\end{array}$ & 21 & 0.32 \\
\hline 11. & $\begin{array}{l}\text { Total expenditure on medicine (Water Related } \\
\text { Diseases) per year }\end{array}$ & 299706 \\
\hline 12. & $\begin{array}{l}\text { Expenditure percentage on medicine of total in- } \\
\text { come }\end{array}$ & $8.09 \%$ \\
\hline
\end{tabular}

* 1 USD equivalent to Rs. 64.4 at the time of study.

$6,1-26,2013$

\section{Measures for safe drinking water}
M. A. Tahir and
H. Rasheed

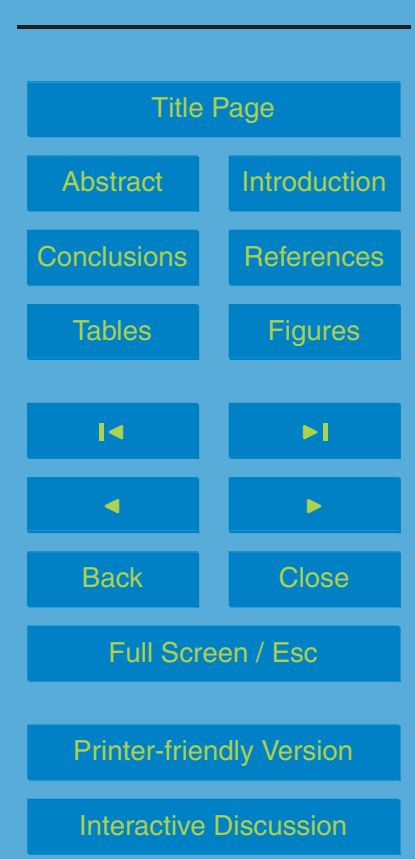


Table 6. Recommended basic requirements for human needs.

\begin{tabular}{lll}
\hline Usage & $\begin{array}{l}\text { Recommended } \\
\text { Lit./person/day }\end{array}$ & $\begin{array}{l}\text { Range Lit./ } \\
\text { person/day }\end{array}$ \\
\hline Drinking water & 5 & 2 to 5 \\
Sanitation services & 20 to 75 & - \\
Bathing & 15 & 5 to 70 \\
Cooking and kitchen & 10 & 10 to 50 \\
\hline Total recommended basic water requirements & 50 & - \\
\hline
\end{tabular}


Table 7. Total cost for disinfection of drinking water in study area.

\begin{tabular}{|c|c|c|c|c|c|}
\hline \multirow{2}{*}{$\begin{array}{l}\text { Sr. } \\
\text { No. }\end{array}$} & \multirow[t]{2}{*}{ Item } & \multirow{2}{*}{$\begin{array}{l}\text { Per unit } \\
\text { Cost (Rs) }\end{array}$} & \multirow[t]{2}{*}{ Requirement } & \multicolumn{2}{|l|}{ Total Cost } \\
\hline & & & & $\begin{array}{l}\text { Pak-Rupees } \\
\text { (Rs.) }\end{array}$ & USD \\
\hline 1 & $\begin{array}{l}\text { Tri-Chloro-Iso- } \\
\text { Cyanuric Acid (TCICA) }\end{array}$ & $277 /-$ & $300 \mathrm{Kg}$ & $83205 /-$ & 12800.00 \\
\hline 2 & Cost of Chlorinator & $50000 /-$ & $\begin{array}{l}\text { based on } 10 \mathrm{yr} \text { life } \\
\text { span }\end{array}$ & $5000 /-$ & 77.00 \\
\hline 3 & Man power (Operator) & $4000 /-$ & 12 months & $48000 /-$ & 738.00 \\
\hline 4 & $\begin{array}{l}\text { Total Expenditures for } \\
\text { safe water supplies } \\
\text { per year }\end{array}$ & - & $\begin{array}{l}1191 \text { family mem- } \\
\text { bers (155 fami- } \\
\text { lies @ }>7 \text { mem- } \\
\text { bers/family) }\end{array}$ & $136205 /-$ & 13615.00 \\
\hline
\end{tabular}

\section{Measures for safe drinking water}
M. A. Tahir and
H. Rasheed

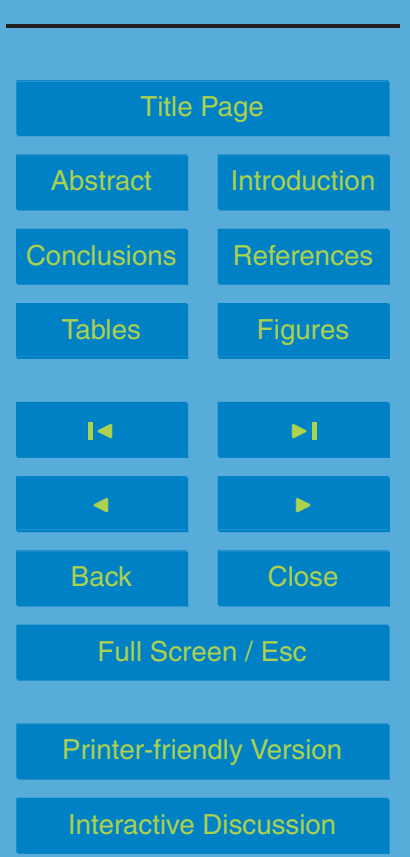

Interactive Discussion

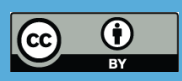


Table 8. Total cost for improvement of water and sanitation condition.

\begin{tabular}{llll}
\hline \multirow{2}{*}{$\begin{array}{l}\text { Sr. } \\
\text { No }\end{array}$} & & \multicolumn{2}{c}{ Total Cost } \\
\cline { 3 - 4 } & & Pak-Rupees (Rs.) & USD \\
\hline 1 & Safe water supplies per year & Rs. 136 205/- & 2095.00 \\
\hline 2 & $\begin{array}{l}\text { Improvement of sanitation } \\
\text { facilities per year }\end{array}$ & Rs. 44849/- & 690.00 \\
\hline 3 & $\begin{array}{l}\text { Total cost to improve water } \\
\text { and sanitation facilities }\end{array}$ & Rs. 181 054/- & 2785.00 \\
\hline
\end{tabular}

6, 1-26, 2013

Measures for safe drinking water
M. A. Tahir and
H. Rasheed

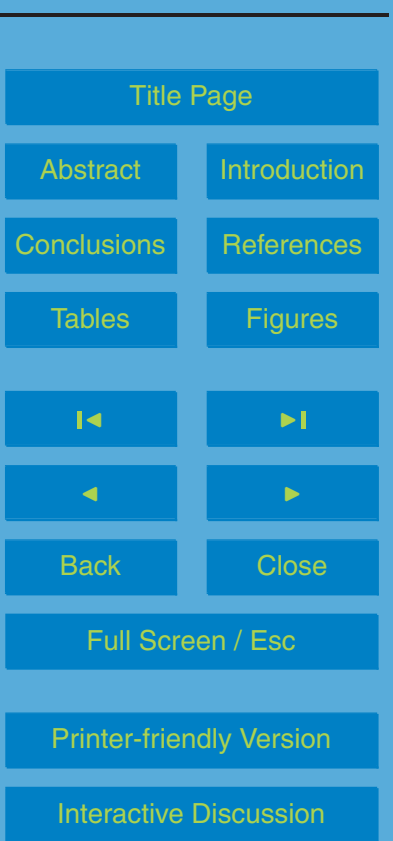


Table 9. Share in different categories.

\begin{tabular}{llll}
\hline $\begin{array}{l}\text { Sr. } \\
\text { No. }\end{array}$ & $\begin{array}{l}\text { Water Related } \\
\text { Diseases }\end{array}$ & $\begin{array}{l}\text { Total Patients } \\
(\text { No.) }\end{array}$ & $\begin{array}{l}\text { Overall Share (\%) of } \\
\text { Each Disease from } \\
\text { Total Population }\end{array}$ \\
\hline$C_{\text {DW }}$ & Category (16.04\%) & \\
\hline 1 & Dysentery & 93 & 7.81 \\
2 & Enteric Diarrheas & 21 & 1.76 \\
3 & Cholera & 27 & 2.27 \\
4 & Typhoid & 7 & 0.59 \\
5 & Goiter & 26 & 2.18 \\
6 & Ascaries & 2 & 0.17 \\
7 & Others & 15 & 1.26 \\
\hline$P_{\mathrm{S}}$ Category (10.08\%) & & \\
\hline 8 & Scabies & 84 & 7.05 \\
9 & Hook Worm & 36 & 3.03 \\
\hline UH & Category (6.72\%) \\
\hline 10. & Malaria & 6.72 \\
\hline
\end{tabular}

6, 1-26, 2013

\section{Measures for safe drinking water
M. A. Tahir and
H. Rasheed

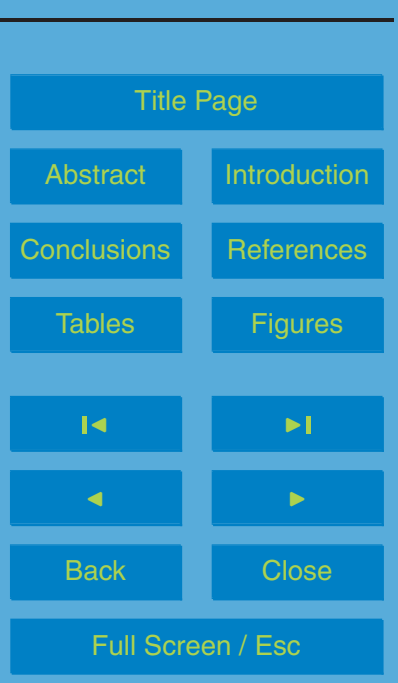

Printer-friendly Version

Interactive Discussion 


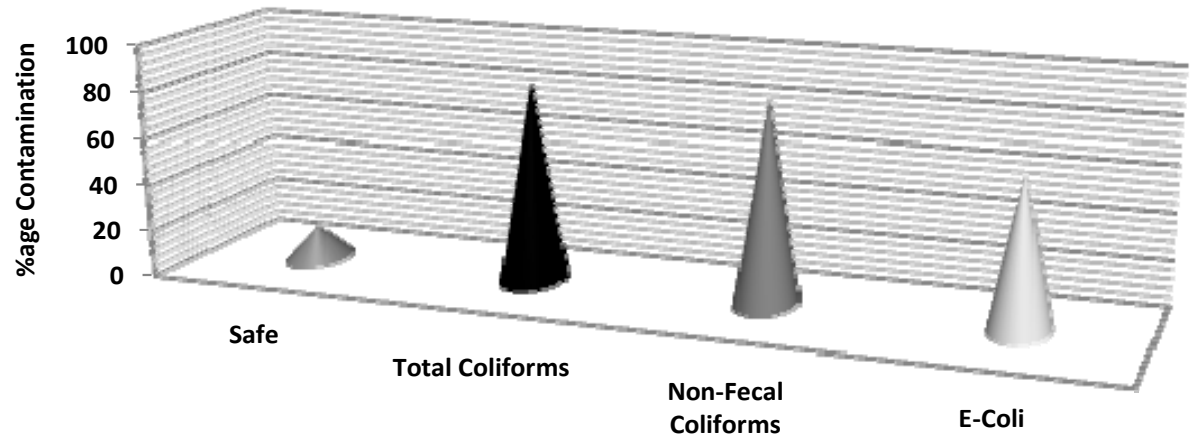

Fig. 1. Bacterial contamination in Gujar Khan.

\section{Measures for safe drinking water \\ M. A. Tahir and \\ H. Rasheed}

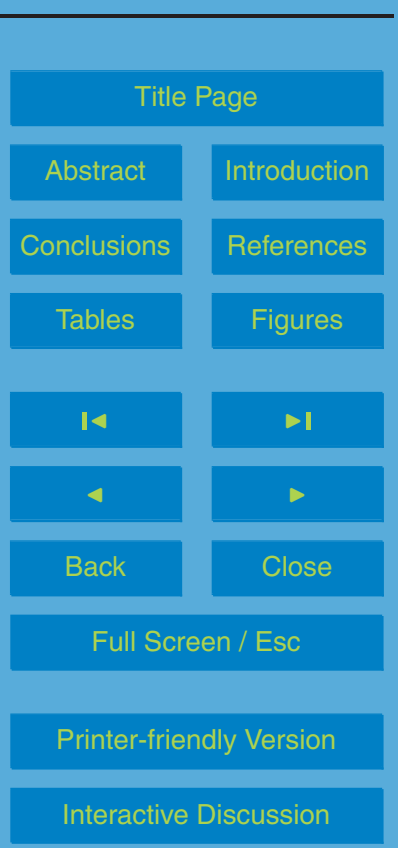

(c) 


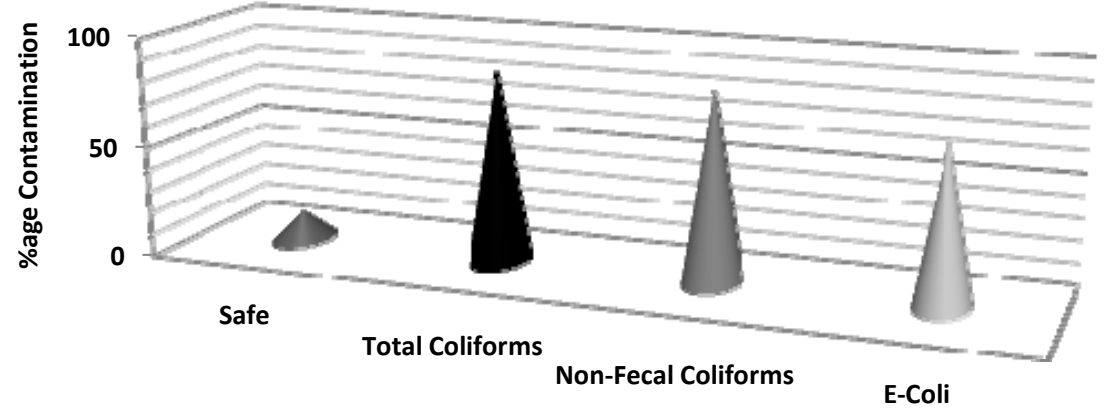

Fig. 2. Bacterial contamination in Murree.

\section{Measures for safe drinking water
M. A. Tahir and
H. Rasheed

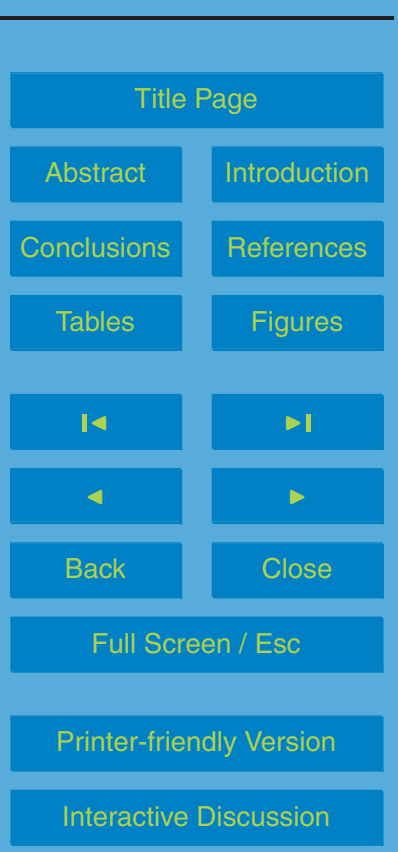

(c) 


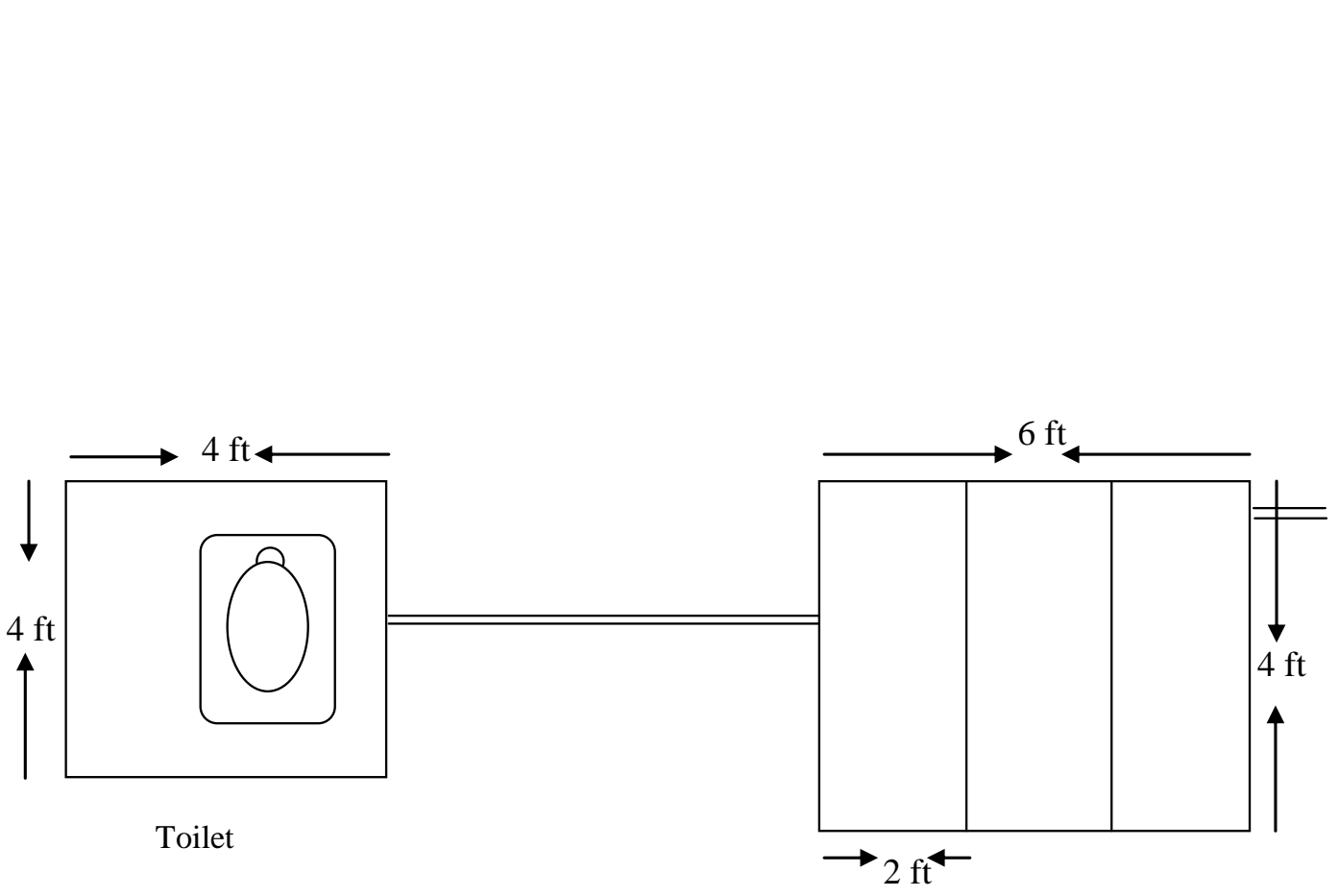

Fig. 3. Horizontal X-section of the Toilet.

\section{DWESD}

6, 1-26, 2013

\section{Measures for safe drinking water
M. A. Tahir and
H. Rasheed

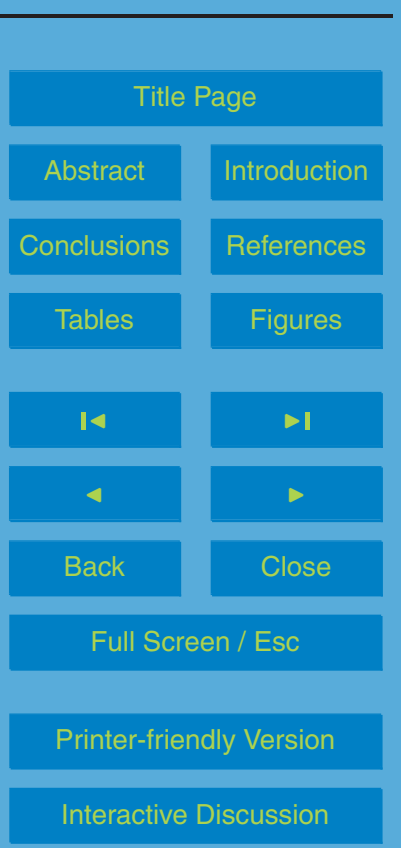




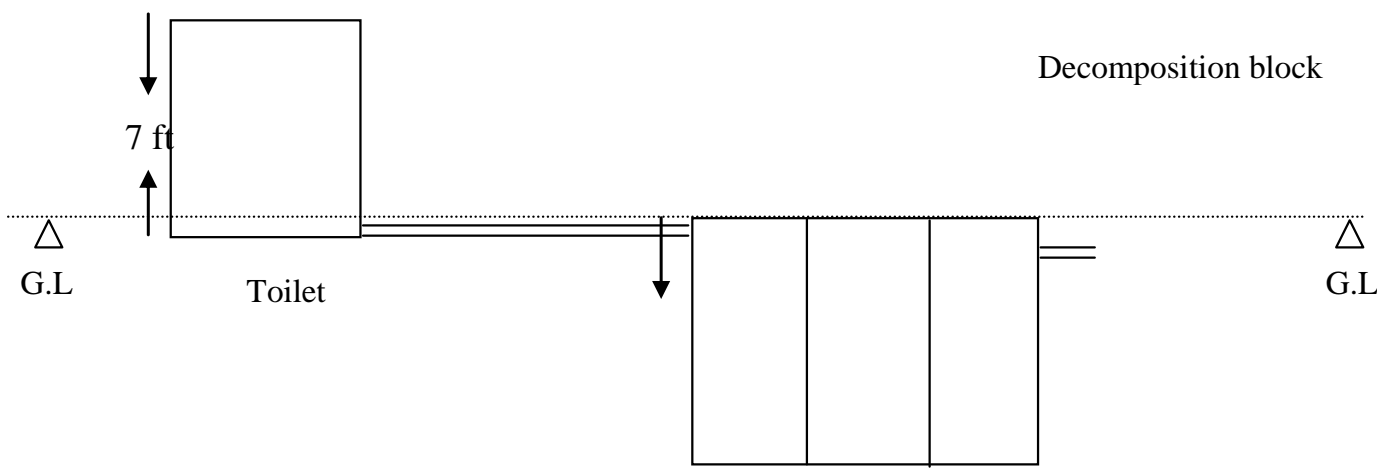

G.L

Fig. 4. Vertical X-section of the Toilet.

\section{Measures for safe drinking water
M. A. Tahir and
H. Rasheed

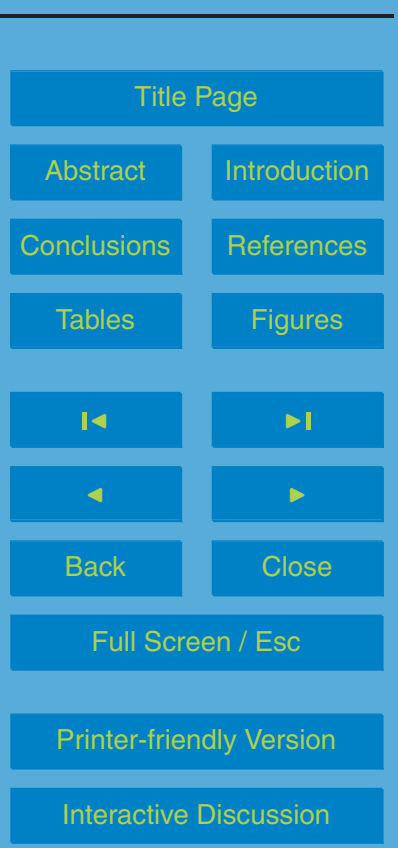

